Saint Louis University School of Law

Scholarship Commons

All Faculty Scholarship

2021

\title{
Ending the War on People with Substance Use Disorders in Health Care
}

Kelly K. Dineen

Creighton University School of Law

Elizabeth Pendo

Saint Louis University School of Law

Follow this and additional works at: https://scholarship.law.slu.edu/faculty

Part of the Civil Rights and Discrimination Commons, and the Health Law and Policy Commons

\section{Recommended Citation}

Dineen, Kelly K. and Pendo, Elizabeth, Ending the War on People with Substance Use Disorders in Health Care (April 24, 2021). 21(4) Amer. J. Bio. 20 (2021); Saint Louis U. Legal Studies Research Paper No. 2021-19.

This Abstract is brought to you for free and open access by Scholarship Commons. It has been accepted for inclusion in All Faculty Scholarship by an authorized administrator of Scholarship Commons. For more information, please contact erika.cohn@slu.edu, ingah.daviscrawford@slu.edu. 


\title{
S A I N T L O U IS \\ $\begin{array}{llllllllll}U & N & \text { I } & V & E & R & S & \text { I } & T & Y\end{array}$ \\ SCHOOL OF LAW
}

\section{SAINT LOUIS UNIVERSITY SCHOOL OF LAW Legal Studies Research Paper Series}

\author{
No. $2021-19$
}

Ending the War on People with Substance Use Disorders in Health Care

Kelly K. Dineen

Creighton University School of Law

Elizabeth Pendo

Saint Louis University-School of Law

21(4) Amer. J. Bio. 20 (2021) 


\title{
Ending the War on People with Substance Use Disorders in Health Care
}

21(4) Amer. J. Bio. 20 (2021)

Kelly K. Dineen

Creighton University School of Law

Elizabeth Pendo

Saint Louis University - School of Law

\begin{abstract}
$\underline{\text { Abstract }}$
Earp et al. (2021) provide a robust justification for the decriminalization of drugs based on the systemic racism that fuels the "war on drugs" and the ongoing harms of drug policies to individuals. The authors' call for decriminalization is a necessary but insufficient step in addressing the entrenched structural, institutional, and individual discrimination that leads to the inequitable and unjust treatment of people with substance use disorder (PWSUD). Nothing short of robust enforcement of existing legal protections and sweeping legal reforms in the regulation of addiction treatment, controlled substances, health care finance, and civil rights law will be adequate to achieve equity and remedy the malignant injustice in this area. This commentary addresses the widespread subrogation of PWSUD in the health care system, which is characterized by the disempowerment, disparagement, and sometimes outright abandonment of patients - a persistent pattern of mistreatment that would spark outrage and condemnation for people with any other health condition.
\end{abstract}

Keywords: health care, health discrimination, substance use disorder, SUD, health disparities, opioid use disorder, OUD, medication for opioid use disorders, MOUD

\section{Suggested Citation:}

Dineen, Kelly K. and Pendo, Elizabeth, Ending the War on People with Substance Use Disorders in Health Care (April 24, 2021). 21(4) Amer. J. Bio. 20 (2021); Saint Louis U. Legal Studies Research Paper No. 2021-19. 